\title{
THE IMPORTANCE OF ROMANIAN MOUNTAIN TOURISM FOR THE NATIONAL ECONOMY
}

\author{
Ungureanu Adrian ${ }^{1}$
}

\begin{abstract}
Why is mountain tourism so important? Here is a question which the author tried to answer to, bringing into account some scientific arguments to support my point of view. First of all, the Carpathians have a variety of large areas of wildness, therefore, of many balanced ecosystems which acomodate all or almost all species and habitats. Their greatest value lies in the fact that they have existed and they still exist in a natural way, and their normal cycle of life flows as close to normal as possible. So, in full symbiosis with these ecosystems, winter sport tourism represents a niche that Romania does not fructify enough.

Information base has formed scientific publications of Romanian and foreign authors related to the problem under consideration and the supplies statistics tourist potential of INS, data reports county division of statistics from 2004 to 2014 and other official documents in Romania, Regional Development Ministry materials and public administration, as well as forecasts, author's calculations and estimates.
\end{abstract}

Key words: mountain tourism, accomodation structures, mountain resorts.

JEL: L83, Q26, Q56

\section{Introduction}

In the classification of types of tourism, mountaneering owns an important place because mountain was always one's favourite place for recovering, resting and adventure, or other socio-cultural needs. The mountain area has drawn the attention of investors and tourism organizers, due to the opportunities for an effective development of tourism activities, thus, nowadays we can talk about the existence on a global scale of a complex, diverse and very attractive offer that suits all people's tastes and types. The importance of mountain areas in the holiday demand has raised concerns of experts who want to exploit this touristic destination in the most efficient manner. (Firoiu, 2002).

1 Ungureanu Adrian, Ph.D., Lecturer, Petroleum-Gas University of Ploieşti, Faculty of Economic Sciences, B-dul Bucuresti no. 39, 100680 Ploieşti, Prahova, Romania, Phone: +40 723561 211, E-mail: ungureanu adrian2001@yahoo.com. 
Along with the growth of tourism in the last decades, mountain caught the attention of investors and promoters of this form of tourism, because of its great ability to create oportunities for economical activities with good results. The effects of mountain tourism development regarding economical and social areas are seen as being very important (Olaru, 2011).

The same thing applies to the environmental impact of mountain tourism, becoming at this time the obvious necessity to promote a sustainable development in mountain areas and to intensify protective measures. The demand for mountain tourism not only experienced an increasing trend worldwide but also major changes in terms of encouraging driving, influenced by various economical, socio-demographic, psychological, and political factors. These two main and interdependent facts that form the essence of mountain tourism' evolution, represent the diffusion of mountain tourism on a social level and the extension of massifs arrangements. (Erdeli, Gheorghilaş, 2006).

Tourist activity, at today's complexity level, involves many aspects and current problems of today's society, from sustainable development (and the associated concept of "responsible tourism") to territorial and social cohesion, being not only a revenue generating economic activity but also the means to develop and revive areas that have lost their economic competitiveness (Neacu, Negu, Vlăsceanu, 2014).

\section{Methodology and data sources}

To make a proper forecast for the next five years of the number of overnights and total arrivals, three adjustment methods will be used, the linear trend method, average time index method and average absolute change. After comparing the coefficient of variation obtained for every method with the $5 \%$ limit on the data shown above, the method with the lowest value will be chosen for the forecast.

Information base has formed scientific publications of Romanian and foreign authors related to the problem under consideration and the supplies statistics tourist potential of INS, data reports county division of statistics from 2004 to 2014 and other official documents in Romania, Regional Development Ministry materials and public administration, as well as forecasts, author's calculations and estimates.

\section{The tourism potential in mountain resorts}

Winter sports generate a tourism flow of approximately 330 million visitors which return revenues up to \$40-55 billion annually (Taylor, Yang, Strom, 2007) and are practiced on all five continents. Skiing as a past-time activity came to be around the turn of the last century in more than in one place of the Alpine countries, but it is in 1908 that in Briançon - Montgènevre is organized the first International Ski Competition and in 1927 in the ski resort of Chamonix the first cable transportation ever-started functioning (Popescu, 2010).

The mountain has always been a special attraction to people since ancient times, which was considered the dwelling of the Gods, but then, with the passing of time, the interest 
has revolved mostly around the admiration for beautiful and unique landscapes developed under this landform; the high altitudes, the abrupt difference of level, the rocks form, saddles, color, gaps, caves, specific vegetation and fauna, clean waters rich in minerals, and also an invigorating climate with important remedies for respiratory and circulation diseases and movement makes the mountain area a tourist location extremely visited for leisure holidays. (Efros, Cheia, 2013).

Shape mountain areas, which includes the Carpathians range area, carried out at altitudes by a few hundred meters at 2,544 m, with an average altitude of $950 \mathrm{~m}$, a high degree of fragmentation, imposed by the many mountain depressions, deep valleys and low forests, a situation that encouraged both the conduct settlements, as well as an intense movement of people (Turnock, 1999).

Mountain Areas is overlapping almost 100\% with the Carpathian Mountains. The average elevation value of the Carpathian Mountains is $1,136 \mathrm{~m}$, and the highest values of altitude are over 2,500 meters. Agricultural area present in Mountain region is around 2,802,000 ha. Out of this area, in 2007, only 1,290,000 ha (46\%) was under commitment, but is estimated that in 2015 will be under commitment around 2,520,000 ha (90\%) and this threshold is unlikely to be higher because of eligibility criteria that are referring to plots and farm sizes. Due to natural restrictive condition (slope and altitude), Carpathian Mountains encounter obstacles in farming, with a negative consequence (a shorter period of vegetation period and supplementary costs). Also, the mountain regions are characterized by a low productivity and depopulation (Antonescu, 2014).

The Carpathians represent the highest geographical unit from Romania, being considered central, both as a layout, but also as a geographical skeleton for the rest of the natural geographical units whose evolution, in the recent geological periods, was closely connected to that of the mountains, their physical and geographical characteristics being strongly influenced by the Carpathian sector. The layout of the Carpathian sector in the Romanian territory is quite unique, the mountain arc including the Eastern and Southern Carpathians, and also the lower and less compact sector of the Western Carpathians (Lesenciuc, Boengiu, Huupau, 2013).

The Eastern Carpathians represent the most extensive group of Romanian Carpathians, with an area of $34,500 \mathrm{~km}^{2}$ (more than $50 \%$ of Romanian Carpathian range area) and with a width of between more than $150 \mathrm{~km}$, in the North, and $80 \mathrm{~km}$, in the bending sector. The age living in these mountains is attested by the paleolithic vestiges of cultures Oaş Depression from Râşnov, Sita Buzău, etc. Much more various are the traces of neolithic settlements and also from the Bronze age. Dacian existence in Piatra Neam (Petrodava), Rasnov (Cumidava) and Covasna highlights the continuous presence in the Middle Ages, the population being organized in unions of rural communities and countries ( Barsei Country, Maramures Country, Oas Country, Nasaud Country, etc.). (Cândea, Bran, 2001)

The Southerners Carpathians have an area of $14,040 \mathrm{~km}^{2}(21 \%$ of the mountain area in Romania) and extend to a length of $250 \mathrm{~km}$, in the East-West direction between Prahova Valley, and Timiş-Cerna tectonic corridor. They are divided into groups such as: Bucegi 
Mountains, Fagaras Mountains, Parang Mountains, Retezat Mountains, which include massifs and some depressions. They have been formed in the Alpine orogeneza (cretacic medium and superior) and are composed of crystalline schists and Mesozoic sedimentary rocks. (Cândea, Bran, 2001)

The Western Carpathians are carried out in the west valleys between Some and Barcau in the North, and the Danube, in the South, occupying an area of $17,714 \mathrm{~km}^{2}$ (about $27 \%$ of Romanian Carpathians area). It represents the most fragmented and the lowest sector, with an average altitude of 1,650 $\mathrm{m}$ and a maximum of 1,849 $\mathrm{m}$ owned by Cucurbata Mare Mountain. Their subdivisions are The Apuseni Mountains, the Banat Mountains and The Poiana Ruscă Mountains . (Cândea, Bran, 2001)

In the exploitation of mountain resources there are important the following aspects:

Landscape looks different, giving originality and the attractiveness of mountain massifs;

- $\quad$ Embossed with average height (800-1,600m), attractive tourism effort, outdoor activities;

- The nature wilderness for the most part;

- A refundable financial aid relatively vast and an assurance of snow at low altitudes $(1,000-1,500 \mathrm{~m})$, required by practicing sports winter;

- Population keeping traditions, traditional houses of quality and an important cultural heritage;

- Tourist potential complex, because of natural resources and recreation are being developed many forms of tourism. (Erdeli, Gheorghilaş, 2006).

The mountain area is characterized by a great variety of tourist resources. The mountain relief impresses through altitude, spectacular cliffs, picturesque ridges and a variety of genetic types of relief: karsts (keys, valleys, caves, steepness, and defiles); volcanic (craters, cones, trays); on conglomerates (sphinxes, mushrooms, towers); massive relief of high mountains (ridges, steep peaks, impressive edges), glacial (glacial amphitheatres, glacial valleys, stony ridges) (Slusariuc, Bîcă, 2015).

\section{Evolution of accommodation structures in mountain resorts}

Exploiting tourism heritage mountain resorts in Romania involves in addition to natural resources, anthropogenic and means appropriate materials, able to ensure fulfilment of requirements tourists throughout the period of their stay. These means are known under the name of the techno-material, which conceals a series of miscellaneous structures: units of accommodation and food, means of transport and leisure facilities (Stănciulescu, Micu, 2009).

The basic material of mountain tourism is partly outdated, the absence of modernisations affects the quality of service offered to tourists in the area (Arsene, 2009). The network of units of receipt in the mountain resorts is unevenly spread, emphasizing greater 
concentrations hosted in Prahova and Brasov counties. In the construction of mountain resorts a special attention has been given to hotels (which take various forms - hotels, chalets, boarding houses, holiday houses, etc. ) and catering, as well as specific fittings winter sports. These components term a functioning system which reflect concepts and ways of adapting to the conditions specific morphological and climatic space mountain, characterized by and refer to a sort of fragility, which may influence the values and the opportunities and thus, undermine the attractiveness of tourist arrangements. (Dezsi, 2006).

According to the study carried out, the number of units of accommodation in mountain area of Romania in 2014 has increased at 1,609 approximately $26.25 \%$ of the total number of units of accommodation in Romania. Throughout the period in question, 2004-2014, the number of defective units of accommodation in mountain resorts experienced a growth trend, from 850 units in 2004 to 1,609 units of accommodation in 2014.

Chart 1. Evolution of accommodation structures in the Romanian mountain resorts, 2004-2014

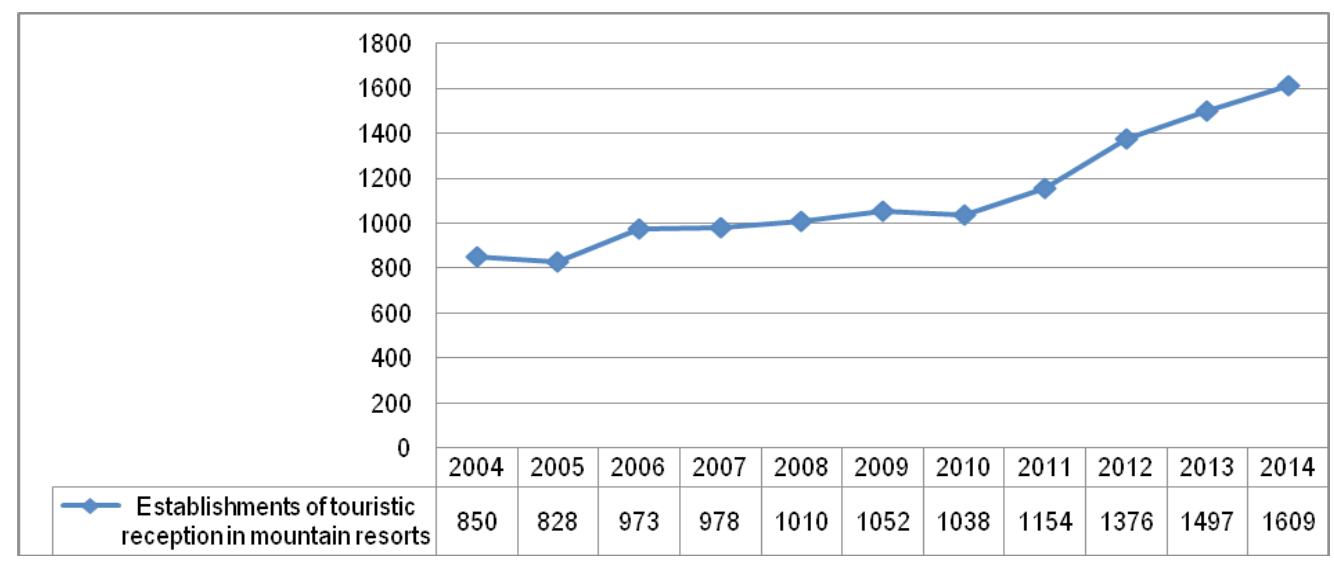

Source: Own calculations based on https://statistici.insse.ro/shop/index.jsp?page=tempo3\&lan $\mathrm{g}=$ ro\&ind $=$ TUR101B 
Table 1. Evolution of accommodation structures in the Romanian mountain resorts, 2004-2014

\begin{tabular}{|c|c|c|c|c|c|c|c|c|c|c|c|}
\hline \multirow{3}{*}{ Year } & \multicolumn{3}{|c|}{ Absolute indicators } & \multicolumn{4}{|c|}{ Relative indicators } & \multicolumn{4}{|c|}{ Annual average } \\
\hline & \multirow{2}{*}{$\begin{array}{c}\text { Level indicators } \\
\text { Accommodation } \\
\text { structures in } \\
\text { the Romanian } \\
\text { mountain resorts }\end{array}$} & \multicolumn{2}{|c|}{ Absolute changes } & \multicolumn{2}{|c|}{ Index dynamics } & \multicolumn{2}{|c|}{ Growth rate } & \multirow{2}{*}{$\mathbf{Y}$} & \multirow{2}{*}{$\Delta$} & \multirow{2}{*}{ I } & \multirow{2}{*}{$\mathbf{R}$} \\
\hline & & $\Delta \mathbf{i} / \mathbf{1}$ & $\Delta \mathbf{i} / \mathbf{i}-\mathbf{1}$ & $\mathbf{I i} / \mathbf{1}$ & Ii/i-1 & $\mathbf{R i} / \mathbf{1}$ & $\mathbf{R i} / \mathbf{i}-\mathbf{1}$ & & & & \\
\hline 2004 & 850 & 0 & & & & 0 & & \multirow{11}{*}{ 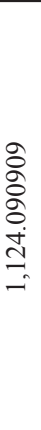 } & \multirow{11}{*}{ 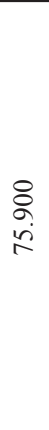 } & \multirow{11}{*}{$\frac{n}{a}$} & \multirow{11}{*}{$\begin{array}{l}2 \\
0 \\
0 \\
0\end{array}$} \\
\hline 2005 & 828 & -22 & -22 & 0.97 & 0.97 & -0.03 & -0.03 & & & & \\
\hline 2006 & 973 & 123 & 145 & 1.14 & 1.18 & 0.14 & 0.18 & & & & \\
\hline 2007 & 978 & 128 & 5 & 1.15 & 1.01 & 0.15 & 0.01 & & & & \\
\hline 2008 & 1,010 & 160 & 32 & 1.19 & 1.03 & 0.19 & 0.03 & & & & \\
\hline 2009 & 1,052 & 202 & 42 & 1.24 & 1.04 & 0.24 & 0.04 & & & & \\
\hline 2010 & 1,038 & 188 & -14 & 1.22 & 0.99 & 0.22 & -0.01 & & & & \\
\hline 2011 & 1,154 & 304 & 116 & 1.36 & 1.11 & 0.36 & 0.11 & & & & \\
\hline 2012 & 1,376 & 526 & 222 & 1.62 & 1.19 & 0.62 & 0.19 & & & & \\
\hline 2013 & 1,497 & 647 & 121 & 1.76 & 1.09 & 0.76 & 0.09 & & & & \\
\hline 2014 & 1,609 & 759 & 112 & 1.89 & 1.07 & 0.89 & 0.07 & & & & \\
\hline
\end{tabular}

Source: Own calculations based on https://statistici.insse.ro/shop/index.jsp?page=tempo3\&lan $\mathrm{g}=\mathrm{ro \& ind}=\mathrm{TUR} 101 \mathrm{~B}$

For the period under consideration, the number of units of accommodation in the mountain resorts of Romanian knew a downward trend of growth, within a fairly short period, of 10 years, the number of increasing by 107\% (2014 reported to 2004).

In order to make an assessment of the evolution trend in the following perspective of the accommodation structures, we used the criterion based on the average change:

Table 2. The calculation algorithm needed to adjust the number of accommodation units through the average growth $\operatorname{method}\left(\mathrm{y}_{\mathrm{t}}\right), 2004-2014$

\begin{tabular}{|c|c|c|c|c|c|}
\hline Year & $\mathbf{y}_{\mathrm{t}}$ & $\Delta_{t / t-1}$ & $\mathrm{t}-1$ & $Y_{t}=y_{1}+(t-1) \Delta$ & $\left(y_{t}-Y_{t}\right)^{2}$ \\
\hline 2004 & 850 & 0 & 0 & 0 & 0 \\
\hline 2005 & 828 & -22 & 1 & 925.9 & $9,584.41$ \\
\hline 2006 & 973 & 145 & 2 & $1,001.8$ & 829.44 \\
\hline 2007 & 978 & 5 & 3 & $1,077.7$ & $9,940.09$ \\
\hline 2008 & 1,010 & 32 & 4 & $1,153.6$ & $20,620.96$ \\
\hline 2009 & 1,052 & 42 & 5 & $1,229.5$ & $31,506.25$ \\
\hline 2010 & 1,038 & -14 & 6 & $1,305.4$ & $71,502.76$ \\
\hline 2011 & 1,154 & 116 & 7 & $1,381.3$ & $51,665.29$ \\
\hline 2012 & 1,376 & 222 & 8 & $1,457.2$ & $6,593.44$ \\
\hline 2013 & 1,497 & 121 & 9 & $1,533.1$ & $1,303.21$ \\
\hline 2014 & 1,609 & 112 & 10 & 1,609 & 0 \\
\hline Total & 12,365 & & & & $203,545.85$ \\
\hline
\end{tabular}

Source: Own calculations based on https://statistici.insse.ro/shop/index.jsp?page=tempo3\&lang=ro\&ind=TUR101B 


\begin{tabular}{|c|c|}
\hline$\Delta$ & 75.9 \\
\hline$\square$ & $1,124.090909$ \\
\hline Standard deviation $\sigma$ & 136.0300268 \\
\hline Coefficient of variation $v$ & $12.10 \%$ \\
\hline
\end{tabular}

Source: Own calculations based on https://statistici.insse.ro/shop/index.jsp?page=tempo3\&lan $\mathrm{g}=$ ro\&ind $=$ TUR $101 \mathrm{~B}$

The value of $12,10 \%$ of the coefficient of variation suggests that the arithmetic average () of the cronologic series - tourists reception structures for tourists accommodation, has a high degree of interest.

Table 3. Previsions of the number of accommodation units in mountain resorts between 2015-2020

\begin{tabular}{|c|c|c|}
\hline Year & $\mathbf{t}-\mathbf{1}$ & $\mathbf{Y}_{\mathbf{t}}=\mathbf{y}_{\mathbf{1}}+\mathbf{( t - 1 )} \boldsymbol{\Delta}$ \\
\hline $\mathbf{2 0 1 5}$ & 11 & $1,684.9$ \\
\hline $\mathbf{2 0 1 6}$ & 12 & $1,760.8$ \\
\hline $\mathbf{2 0 1 7}$ & 13 & $1,836.7$ \\
\hline $\mathbf{2 0 1 8}$ & 14 & $1,912.6$ \\
\hline $\mathbf{2 0 1 9}$ & 15 & $1,988.5$ \\
\hline $\mathbf{2 0 2 0}$ & 16 & $2,064.4$ \\
\hline
\end{tabular}

Source: Own calculations based on https://statistici.insse.ro/shop/index.jsp?page=tempo3\&lan $\mathrm{g}=\mathrm{ro \& ind}=\mathrm{TUR} 101 \mathrm{~B}$

The previsions in the dynamics of the number of establishments regarding tourists accommodation in mountain resorts between 2015-2020, reveals a constant trend ascending. The trend presents a favorable situation for mountain tourism as a whole and is due to both investments, as well as valorisation of the potential of mountain tourism.

Chart 2. The evolution of accommodation units in mountain resorts in all accommodation units, between 2004-2014

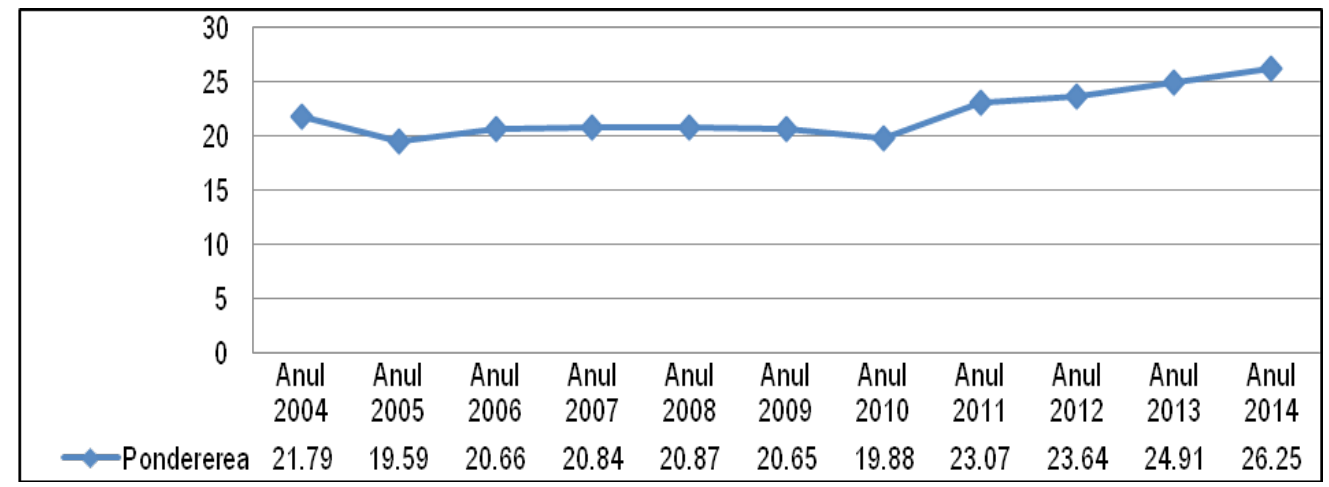

Source: Own calculations based on https://statistici.insse.ro/shop/index.jsp?page=tempo3\&lan $\mathrm{g}=$ ro\&ind $=$ TUR101B 
The increase in the number of accommodation units from the Romanian mountain resorts also determined an increase of total structures in their accommodation. In the analysis of the data from the above chart, it is observed that the share accommodation structures in the mountain resorts has been increased steadily and highlighted. If, at the level of 2004 the share registered a value of 21.79 percent in 2014 , reaches maximum value of $26.25 \%$.

Chart 3. The share of tourist reception establishments, by types of structures in 2004 - (\%)

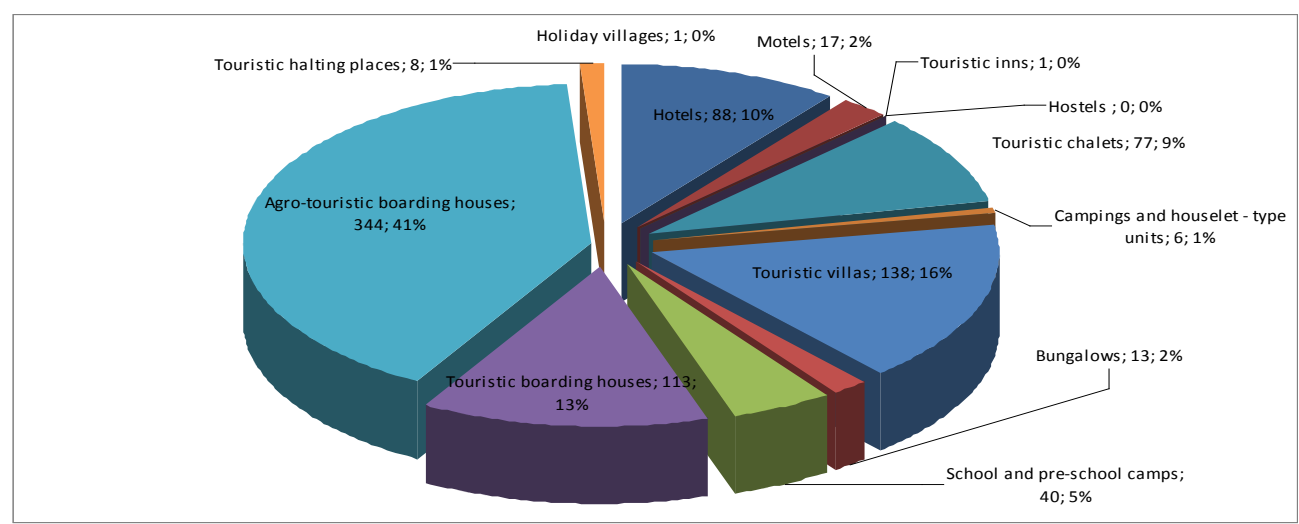

Source: Own calculations based on https://statistici.insse.ro/shop/index.jsp?page=tempo3\&lan $\mathrm{g}=$ ro\&ind $=$ TUR101B

Regarding the share of tourist attraction's facilities, the types of structures in mountain resorts, the first position is held by million Euro are meant for boarding and lodging rural tourism which, along with the tourism integrated $63 \%$ of the total accommodation structures of 2014 . The evolution in number of the units of accommodation, shows that between 2004 and 2014, the number of touristic boarding houses has grown considerably, from 457 (approximately 53 $\%$ ) in 2004 to 1042 (about $63 \%$ ) - see graphs 3 and 4.

Chart 4. The share of tourist reception establishments, by types of structures in 2014 - (\%)

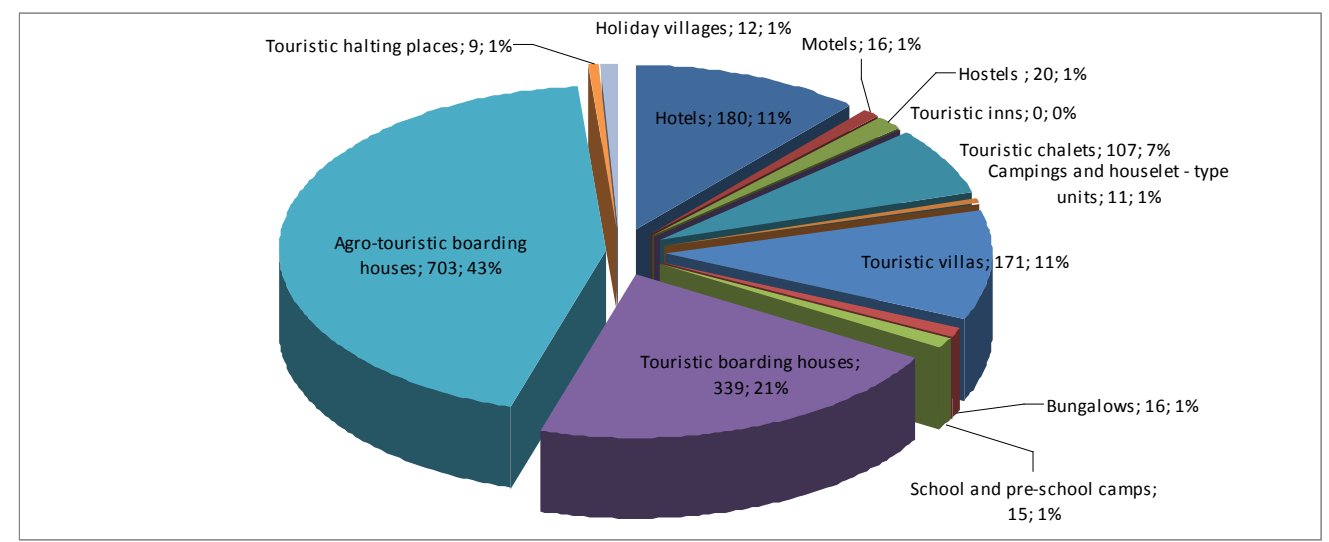

Source: Own calculations based on https://statistici.insse.ro/shop/index.jsp?page=tempo3\&lan $\mathrm{g}=$ ro\&ind $=$ TUR101B 
Even though the number of hotels has increased from 88 in 2004 to 180 in 2014, their weightings in the total of structures of the facilities in mountain resorts, increased by only one percent, from $10 \%$ to $11 \%$. Another visible change is also recorded by touristic villas, which have decreased from $16 \%$ in 2004, to $11 \%$ in 2014 . The percentage relatively large held by tourist villas is due to the fact that the investments, and the costs of their maintenance are lower.

Chart 5. The evolution trend of the number of hotels in the mountain resorts, 2004-2014

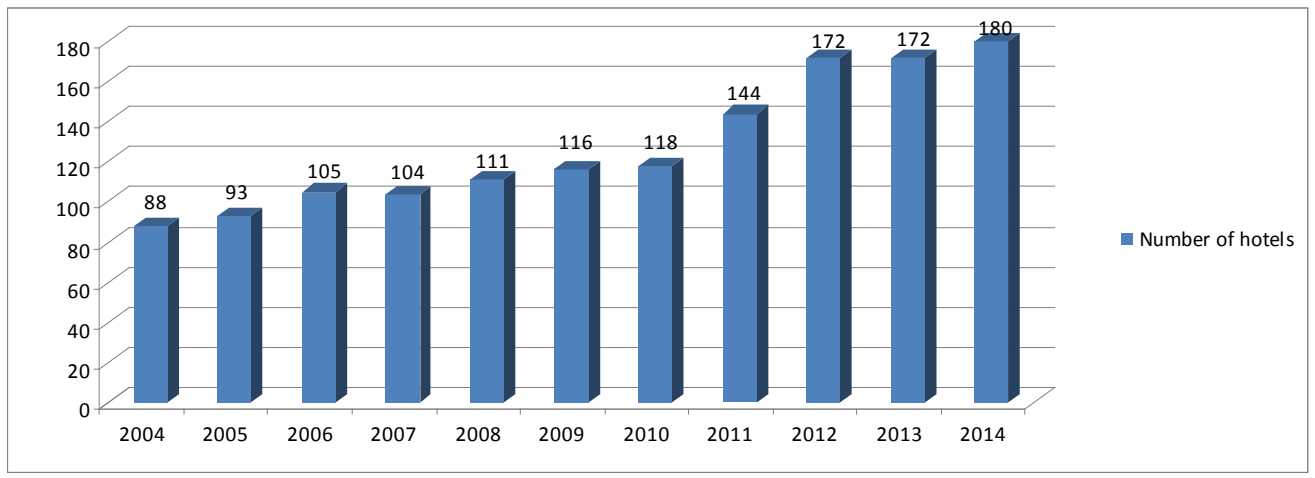

Source: Own calculations based on https://statistici.insse.ro/shop/index.jsp?page=tempo3\&lan $\mathrm{g}=\mathrm{ro} \&$ ind $=\mathrm{TUR} 101 \mathrm{~B}$

Generally, for the proper conduct of tourism activity, but in particular for mountain areas, the accomodation structures like hotels are the most important ones, because they give tourists safety they need along with an adequate price for touristic services offered. (Marin-Pantelescu, 2009).

With a view to assess downward trend in the number of hotels from the mountain resorts for the period 2015-2020 we've used the criterion based on average change obtaining a value of $8.86 \%$ of the coefficient of variation, a fact that suggests the arithmetic mean $(\square)$ of the series historical record - number hotels, has a very high degree of representativeness.

Table 4. The calculation algorithm needed to adjust the evolution trend of the number of hotels through the average growth method $\left(\mathrm{y}_{\mathrm{t}}\right), 2004-2014$

\begin{tabular}{|c|c|c|c|c|c|}
\hline Year & $\mathbf{y}_{\mathbf{t}}$ & $\boldsymbol{\Delta}_{t-1-1}$ & $\mathbf{t}-\mathbf{1}$ & $\mathbf{Y}_{t}=\mathbf{y}_{\mathbf{1}}+\mathbf{( t - 1 ) \boldsymbol { \Delta }}$ & $\left(\mathbf{y}_{\mathbf{t}}-\mathbf{Y}_{\mathbf{t}}\right)^{\mathbf{2}}$ \\
\hline $\mathbf{2 0 0 4}$ & 88 & 0 & 0 & 0 & 0 \\
\hline $\mathbf{2 0 0 5}$ & 93 & 5 & 1 & 97.2 & 17.64 \\
\hline $\mathbf{2 0 0 6}$ & 105 & 12 & 2 & 106.4 & 1.96 \\
\hline $\mathbf{2 0 0 7}$ & 104 & -1 & 3 & 115.6 & 134.56 \\
\hline $\mathbf{2 0 0 8}$ & 114 & 10 & 4 & 124.8 & 116.64 \\
\hline $\mathbf{2 0 0 9}$ & 116 & 2 & 5 & 134 & 324 \\
\hline $\mathbf{2 0 1 0}$ & 118 & 2 & 6 & 143.2 & 635.04 \\
\hline $\mathbf{2 0 1 1}$ & 144 & 26 & 7 & 152.4 & 70.56 \\
\hline $\mathbf{2 0 1 2}$ & 172 & 28 & 8 & 161.6 & 108.16 \\
\hline
\end{tabular}




\begin{tabular}{|c|c|c|c|c|c|}
\hline $\mathbf{2 0 1 3}$ & 172 & 0 & 9 & 170.8 & 1.44 \\
\hline $\mathbf{2 0 1 4}$ & 180 & 8 & 10 & 180 & 0 \\
\hline Total & $\mathbf{1 , 4 0 6}$ & \multicolumn{5}{|l|}{} & $\mathbf{1 , 4 1 0}$ \\
\hline
\end{tabular}

Source: Own calculations based on https://statistici.insse.ro/shop/index.jsp?page=tempo3\&lan $\mathrm{g}=\mathrm{ro \& ind}=\mathrm{TUR} 101 \mathrm{~A}$

\begin{tabular}{|c|c|}
\hline$\Delta$ & 9.2 \\
\hline$\square$ & 127.8181818 \\
\hline Standard deviation $\sigma$ & 11.32174095 \\
\hline Coefficient of variation $v$ & $8.86 \%$ \\
\hline
\end{tabular}

Source: Own calculations based on https://statistici.insse.ro/shop/index.jsp?page=tempo3\&lan $\mathrm{g}=\mathrm{ro \& ind}=\mathrm{TUR} 101 \mathrm{~A}$

Table.5. Previsions of the number of tourist reception establishments in mountain resorts, 2015-2020

\begin{tabular}{|c|c|c|}
\hline Year & $\mathbf{t}-\mathbf{1}$ & $\mathbf{Y}_{\mathbf{+}}=\mathbf{y}_{\mathbf{1}}+\mathbf{( t - 1 ) \boldsymbol { \Delta }}$ \\
\hline $\mathbf{2 0 1 5}$ & 11 & 189.20 \\
\hline $\mathbf{2 0 1 6}$ & 12 & 198.40 \\
\hline $\mathbf{2 0 1 7}$ & 13 & 207.60 \\
\hline $\mathbf{2 0 1 8}$ & 14 & 216.80 \\
\hline $\mathbf{2 0 1 9}$ & 15 & 226.00 \\
\hline $\mathbf{2 0 2 0}$ & 16 & 235.20 \\
\hline
\end{tabular}

Source: Own calculations based on https://statistici.insse.ro/shop/index.jsp?page=tempo3\&lan $\mathrm{g}=\mathrm{ro \& ind}=\mathrm{TUR} 101 \mathrm{~A}$

In accordance to the preview from the table above, for the period 2015-2020, there has been an upward trend, for the dynamics of the number of hotels. The number of hotels will increase the next years, which represents an advantageous situation for the Romanian mountain tourism. This increase can be traced to people's desire to feel the convenience of a hotel with all the facilities, the renovation of the technico-material base for tourism as well as a diversification of the Romanian mountain tourism offer.

Chart 6. The evolution trend of the number of guesthouses and agrotouristic hotels in the mountain resorts, 2004-2014

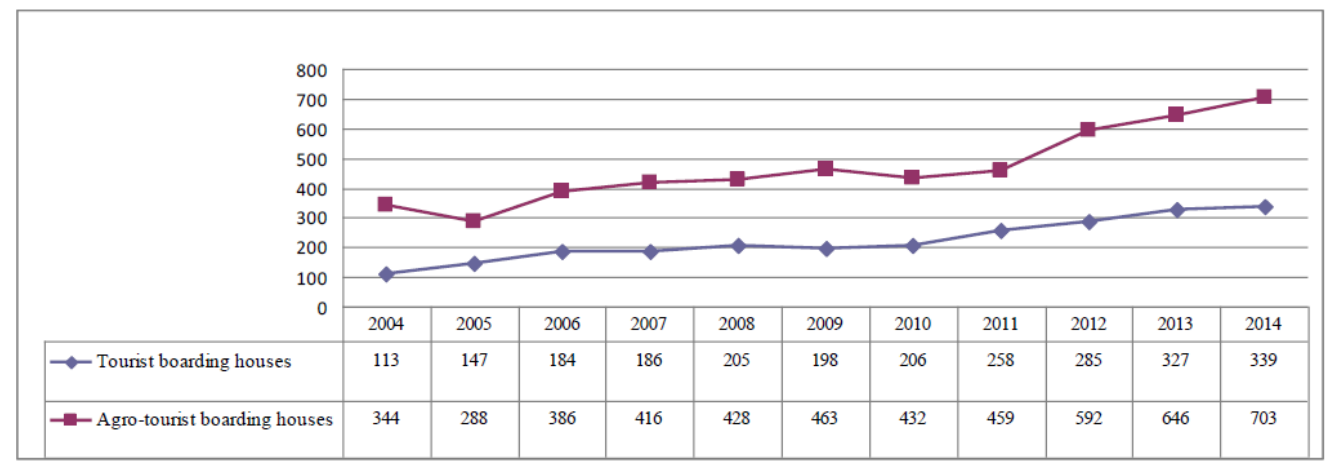

Source: Own calculations based on https://statistici.insse.ro/shop/index.jsp?page=tempo3\&lan $\mathrm{g}=$ ro\&ind $=$ TUR $101 \mathrm{C}$ 
The increase in the number of units of accommodation over the period which has been analyzed, it is due to,on one hand the appearance of new types of touristic structures (tourist and boarding houses, hotels for youth, hostels) and, on the other hand an increasing number of structures classified to higher categories (3-5 stars).

Chart 7. The share of accommodation units on categories of comfort in $2004-(\%)$

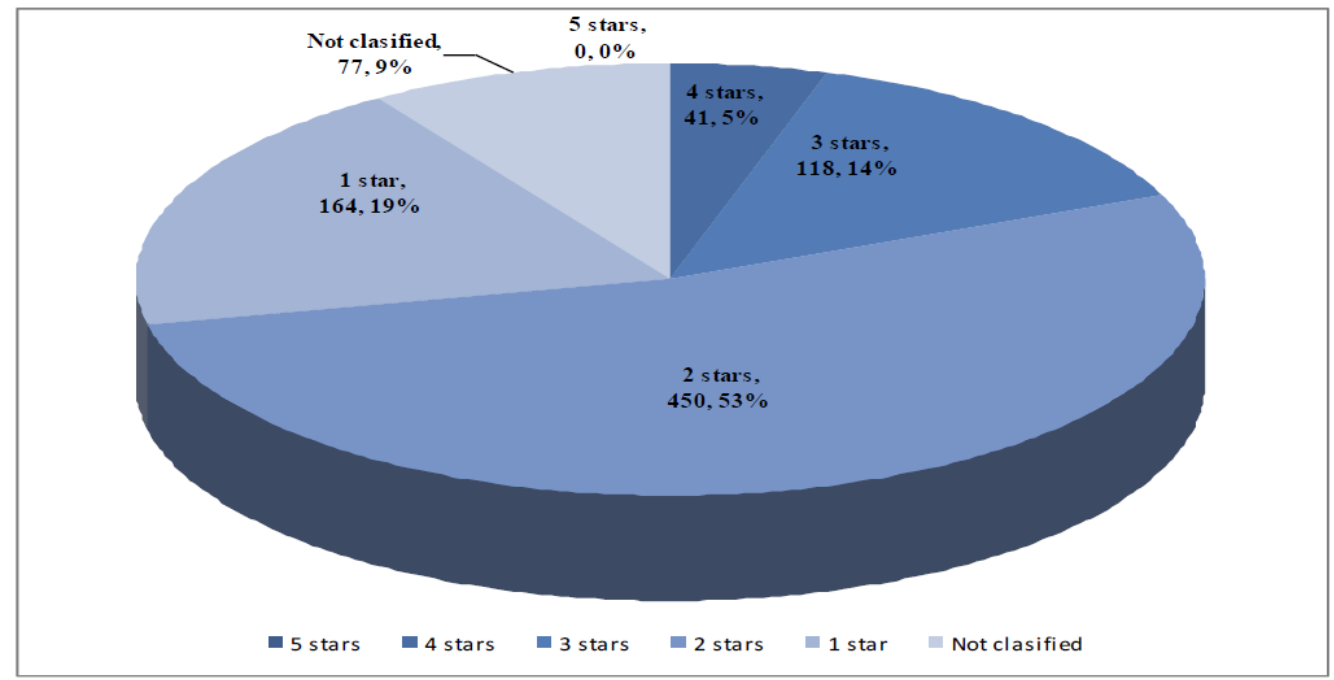

Source: Own calculations based on https://statistici.insse.ro/shop/index.jsp?page=tempo3\&lan $\mathrm{g}=\mathrm{ro} \&$ ind $=\mathrm{TUR} 101 \mathrm{C}$

The current image of Romanian mountain tourism is also offered by the capacity of the accommodation corcerning the category of comfort. If in Europe there is an emphasis on the accommodation structures classified to 4 and respectively 5 stars, in Romania in 2004 were preffered the accommodation structures of the lower categories. According to the data supplied by INSSE and processed in the present work, it is seen that in 2004 the share was owned by the accomodation structures of 2 stars $(53 \%)$, which together with those of 3 stars $(14 \%)$ and respectively a star (19\%) totals $86 \%$. It should be noted that in the base year of the analysis undertaken, in the Romanian mountain resorts, there was not even a single unit of accommodation classified to 5 stars. 
Chart 8. The share of accommodation units on categories of comfort in 2014 - (\%)

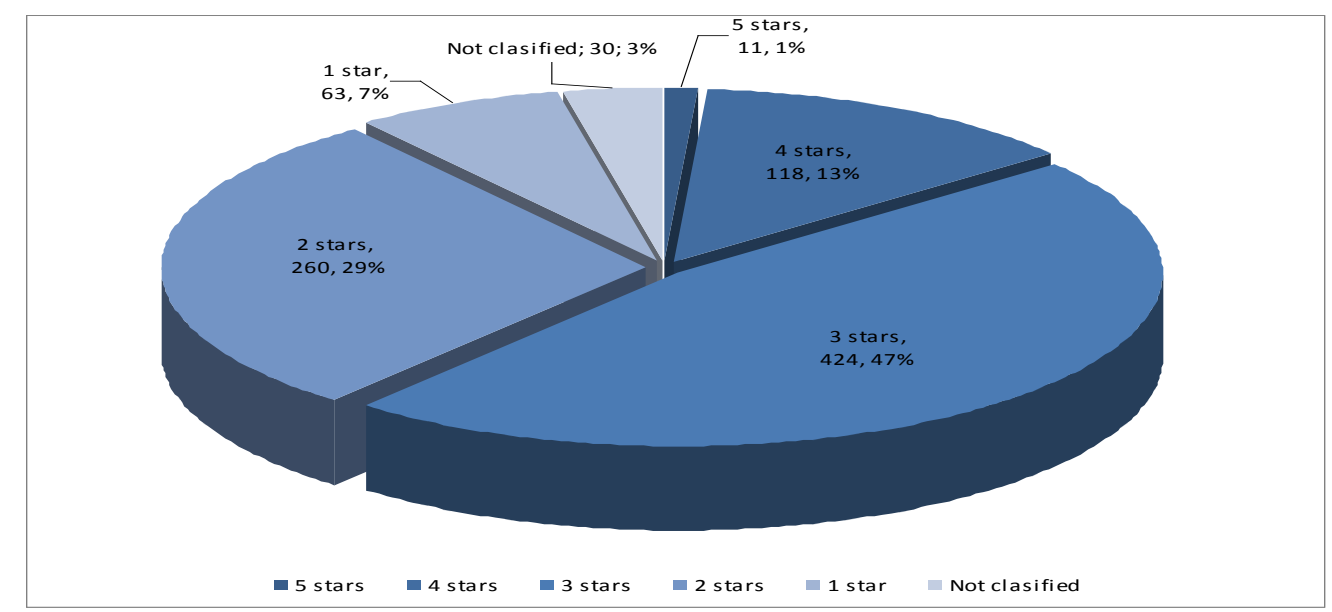

Source: Own calculations based on https://statistici.insse.ro/shop/index.jsp?page=tempo3\&lan $\mathrm{g}=$ ro\&ind $=\mathrm{TUR} 101 \mathrm{C}$

From the point of view of the degree of comfort, in 2014 there is a strong concentration of establishments and the number of accomodation in lower categories, i.e. units of 3 and 2 stars (see charts 7 and 8). This situation may be explained by the units antiquity and by the advanced degree of wearing. To these shortcomings there are teamed up the absence of modernization works and the maintenance of the units already in existence. For the mountain tourism a highpoint represents the rises in the period 2004-2014 to the higher categories.

For instance, to 4 and 5 stars categories, there has been a significant increase, from $5 \%$ in 2004 , to $14 \%$ in 2014. In the case of 4 and 5 stars categories, it is to be noticed an increase in the proportions both in the number of units and in the number of accomodation. By analysing available data, the most significant proportion in the accomodation structures by category of comfort (in mountain resorts) in 2014, it is held by the units of 2 , respectively 3 stars, which together cover $76 \%$ of the total. The weighting of each category of tourist structures facilities is presented in the chart no. 8 .

The situation is slightly different if it is analyzed the ability of accommodation in operation. So, the period 2004-2014 was marked by a loss of up and down movements, from the accommodation capacity of 32,554 in 2004 , to 50,996 in 2014 , as shown in the following table. 
Table 6. The evolution of accommodation capacity in use , 2004-2014 - (mii locuri-zile)

\begin{tabular}{|c|c|c|c|c|c|c|c|c|c|c|c|}
\hline \multirow{3}{*}{ Year } & \multicolumn{3}{|c|}{ Absolute indicators } & \multicolumn{4}{|c|}{ Relative indicators } & \multicolumn{4}{|c|}{ Annual average } \\
\hline & \multirow{2}{*}{$\begin{array}{l}\text { Level indicators } \\
\text { Accommodation } \\
\text { capacity in } \\
\text { the Romanian } \\
\text { mountain } \\
\text { resorts }\end{array}$} & \multicolumn{2}{|c|}{$\begin{array}{l}\text { Absolute } \\
\text { changes }\end{array}$} & \multicolumn{2}{|c|}{$\begin{array}{c}\text { Index } \\
\text { dynamics }\end{array}$} & \multicolumn{2}{|c|}{ Growth rate } & \multirow[b]{2}{*}{$\boldsymbol{Y}$} & \multirow[b]{2}{*}{$\Delta$} & \multirow[b]{2}{*}{$I$} & \multirow[b]{2}{*}{$\boldsymbol{R}$} \\
\hline & & $\Delta_{\mathrm{i} / 1}$ & $\Delta_{\mathrm{i} / \mathrm{i}-1}$ & $\mathbf{I}_{\mathrm{i} / 1}$ & $\mathbf{I}_{\mathrm{i} / \mathrm{i}-1}$ & $\mathbf{R}_{\mathrm{i} / 1}$ & $\mathbf{R}_{\mathrm{i} / \mathrm{i}-1}$ & & & & \\
\hline 2004 & 32,554 & 0 & & & & 0 & & \multirow{11}{*}{$\begin{array}{l}\text { oे } \\
\text { id } \\
\text { o. } \\
\text { m }\end{array}$} & \multirow{11}{*}{ 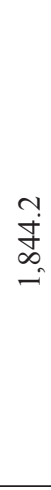 } & \multirow{11}{*}{$\stackrel{\infty}{\sigma}$} & \multirow{11}{*}{ ô. } \\
\hline 2005 & 33,196 & 642 & 642 & 1.02 & 1.02 & 0.02 & 0.02 & & & & \\
\hline 2006 & 32,233 & -321 & -963 & 0.99 & 0.97 & -0.01 & -0.03 & & & & \\
\hline 2007 & 31,448 & $-1,106$ & -785 & 0.97 & 0.98 & -0.03 & -0.02 & & & & \\
\hline 2008 & 32,763 & 209 & 1,315 & 1.01 & 1.04 & 0.01 & 0.04 & & & & \\
\hline 2009 & 35,395 & 2,841 & 2,632 & 1.09 & 1.08 & 0.09 & 0.08 & & & & \\
\hline 2010 & 35,426 & 2,872 & 31 & 1.09 & 1.00 & 0.09 & 0.00 & & & & \\
\hline 2011 & 38,571 & 6,017 & 3,145 & 1.18 & 1.09 & 0.18 & 0.09 & & & & \\
\hline 2012 & 45,427 & 12,873 & 6,856 & 1.40 & 1.18 & 0.40 & 0.18 & & & & \\
\hline 2013 & 48,034 & 15,480 & 2,607 & 1.48 & 1.06 & 0.48 & 0.06 & & & & \\
\hline 2014 & 50,996 & 18,442 & 2,962 & 1.57 & 1.06 & 0.57 & 0.06 & & & & \\
\hline
\end{tabular}

Source: Own calculations based on https://statistici.insse.ro/shop/index.jsp?page=tempo3\&lan $\mathrm{g}=$ ro\&ind $=$ TUR103C

The number of accommodation capacity in the Romanian mountain resorts in the period 2004-2014, can be seen as being fluctuant, recording in 2014 a high point of $157 \%$ compared with 2004, and the minimum value was noted in 2007, 97\%, as compared to 2004. During the period 2004-2014, in the mountain resorts, tourist accommodation capacity has been on an annual average of 37,822.09 places, an increase of 1, 844 positive environmental places, thus representing an annual relative progress of $2 \%$.

Chart 9. The evolution of accommodation capacity in use, 2004-2014 - (mii locurizile)

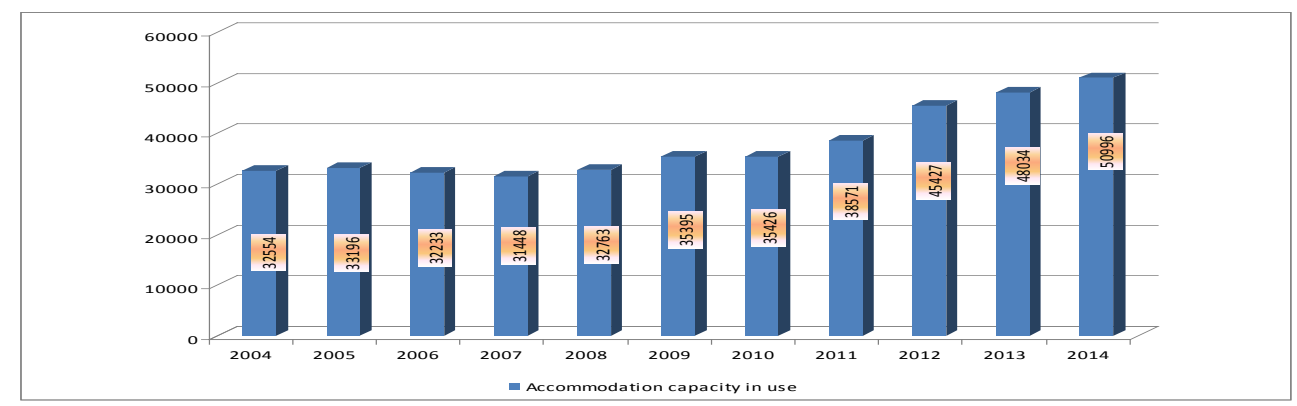

Source: Own calculations based on https://statistici.insse.ro/shop/index.jsp?page=tempo3\&lan $\mathrm{g}=$ ro\&ind $=\mathrm{TUR} 103 \mathrm{C}$ 
Table 7. The calculation algorithm needed to adjust the evolution trend of accommodation capacity in use through the average growth method $\left(y_{t}\right), 2004-2014$

\begin{tabular}{|c|c|c|c|c|c|}
\hline Year & $\mathbf{y}_{\mathbf{t}}$ & $\boldsymbol{\Delta}_{\mathbf{t} / \mathbf{- 1}}$ & $\mathbf{t}-\mathbf{1}$ & $\mathbf{Y}_{\mathbf{t}}=\mathbf{y}_{\mathbf{1}}+\mathbf{( t - 1 ) \mathbf { \Delta }}$ & $\left(\mathbf{y}_{\mathbf{t}}-\mathbf{Y}_{\mathbf{t}} \mathbf{~}^{\mathbf{2}}\right.$ \\
\hline $\mathbf{2 0 0 4}$ & 32,554 & 0 & 0 & 0 & 0 \\
\hline $\mathbf{2 0 0 5}$ & 33,196 & 642 & 1 & $34,398.2$ & $1,445,284.84$ \\
\hline $\mathbf{2 0 0 6}$ & 32,233 & -963 & 2 & $36,242.4$ & $16,075,288.36$ \\
\hline $\mathbf{2 0 0 7}$ & 31,448 & -785 & 3 & $38,086.6$ & $44,071,009.96$ \\
\hline $\mathbf{2 0 0 8}$ & 32,763 & 1,315 & 4 & $39,930.8$ & $51,377,356.84$ \\
\hline $\mathbf{2 0 0 9}$ & 35,395 & 2,632 & 5 & 41,775 & $40,704,400$ \\
\hline $\mathbf{2 0 1 0}$ & 35,426 & 31 & 6 & $43,619.2$ & $67,128,526.24$ \\
\hline $\mathbf{2 0 1 1}$ & 38,571 & 3,145 & 7 & $45,463.4$ & $47,505,177.76$ \\
\hline $\mathbf{2 0 1 2}$ & 45,427 & 6,856 & 8 & $47,307.6$ & $3,536,656.36$ \\
\hline $\mathbf{2 0 1 3}$ & 48,034 & 2,607 & 9 & $49,151.8$ & $1,249,476.84$ \\
\hline $\mathbf{2 0 1 4}$ & 50,996 & 2,962 & 10 & 50,996 & 0 \\
\hline Total & $\mathbf{4 1 6 , 0 4 3}$ & \multicolumn{5}{|l}{} \\
\hline
\end{tabular}

Source: Own calculations based on https://statistici.insse.ro/shop/index.jsp?page=tempo3\&lan $\mathrm{g}=$ ro\&ind $=$ TUR $103 \mathrm{C}$

\begin{tabular}{|c|c|}
\hline$\Delta$ & $1,844.2$ \\
\hline$\square$ & $37,822.09$ \\
\hline Standard deviation $\sigma$ & 4.982 .63 \\
\hline Coefficient of variation $v$ & $13.17 \%$ \\
\hline
\end{tabular}

Source: Own calculations based on https://statistici.insse.ro/shop/index.jsp?page=tempo3\&lan $\mathrm{g}=$ ro\&ind $=$ TUR $103 \mathrm{C}$

Table.8. Previsions of the number of accommodation capacity in use in mountain resorts, 2015-2020

\begin{tabular}{|c|c|c|}
\hline Year & $\mathbf{t}-\mathbf{1}$ & $\mathbf{Y}_{+}=\mathbf{y}_{\mathbf{1}}+\mathbf{( t - 1 ) \boldsymbol { \Delta }}$ \\
\hline $\mathbf{2 0 1 5}$ & 11 & $52,840.20$ \\
\hline $\mathbf{2 0 1 6}$ & 12 & $54,684.40$ \\
\hline $\mathbf{2 0 1 7}$ & 13 & $56,528.60$ \\
\hline $\mathbf{2 0 1 8}$ & 14 & $58,372.80$ \\
\hline $\mathbf{2 0 1 9}$ & 15 & $60,217.00$ \\
\hline $\mathbf{2 0 2 0}$ & 16 & $62,061.20$ \\
\hline
\end{tabular}

Source: Own calculations based on https://statistici.insse.ro/shop/index.jsp?page=tempo3\&lan $\mathrm{g}=$ ro\&ind $=$ TUR $103 \mathrm{C}$

In accordance with the preview from the table above, for the period 2015-2020, there has been an upward trend, the dynamics of accommodation places in the mountain resorts. The number of accommodation places will increase the next few years, which means a favorable situation for the Romanian mountain tourism.

In conclusion, the accomodation offer available in the Romanian mountain tourism must be diversified and upgraded. For this purpose, there are necessary, however, several investments in this domain based on uniform strategies developed at the central level and implemented at the local level. In this respect, tourism supply must be designed to meet tourist demand. 


\section{The tourist circulation indicators in the Romanian mountain resorts}

The tourist circulation analysis implies the knowledge of evolution of some key indicators, namely: the number of tourists who come in the mountain resorts, the number of overnight stays, the tourist's stay, the density of tourist attraction.

\section{Number of tourists}

The number of tourists who prefer the Romanian mountain resorts can be fluctuant, recording in 2013 the maximum of $166 \%$ compared with 2003, and the minimum value has been registered in 2010, as being 109\% compared with 2003 .

Table 9. The evolution of the number of tourists in accommodation units in the mountain resorts, 2003-2013

\begin{tabular}{|c|c|c|c|c|c|c|c|c|c|}
\hline \multirow{3}{*}{ Year } & \multicolumn{3}{|c|}{ Absolute indicators } & \multicolumn{4}{|c|}{ Relative indicators } & \multicolumn{2}{|c|}{$\begin{array}{l}\text { Annual } \\
\text { average }\end{array}$} \\
\hline & \multirow{2}{*}{$\begin{array}{l}\text { Level indicators } \\
\text { Number of tourists in } \\
\text { accommodation units } \\
\text { in mountain resorts }\end{array}$} & \multicolumn{2}{|c|}{ Absolute changes } & \multicolumn{2}{|c|}{$\begin{array}{c}\text { Index } \\
\text { dynamics }\end{array}$} & \multicolumn{2}{|c|}{$\begin{array}{l}\text { Growth } \\
\text { rate }\end{array}$} & I & $\Delta$ \\
\hline & & $\Delta_{\mathrm{i} / 1}$ & $\Delta_{\mathrm{i} / \mathrm{i}-1}$ & $\mathbf{I}_{\mathrm{i} / 1}$ & $\mathbf{I}_{\mathrm{i} / \mathrm{i}-1}$ & $\mathbf{R}_{\mathrm{i} / \mathbf{1}}$ & $\mathbf{R}_{\mathrm{i} / \mathrm{i}-1}$ & & \\
\hline 2003 & 747,830 & 0 & & & & 0 & & \multirow{11}{*}{ 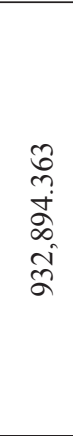 } & \multirow{11}{*}{$\begin{array}{l}\tilde{n} \\
\tilde{n} \\
\tilde{\sigma} \\
\text { ?े }\end{array}$} \\
\hline 2004 & 836,298 & 88,468 & 88,468 & 1.12 & 1.12 & 0.12 & 0.12 & & \\
\hline 2005 & 827,952 & 80,122 & $-8,346$ & 1.11 & 0.99 & 0.11 & -0.01 & & \\
\hline 2006 & 882,846 & 135,016 & 54,894 & 1.18 & 1.07 & 0.18 & 0.07 & & \\
\hline 2007 & 997,742 & 249,912 & 114,896 & 1.33 & 1.13 & 0.33 & 0.13 & & \\
\hline 2008 & 998,468 & 250,638 & 726 & 1.34 & 1.00 & 0.34 & 0.00 & & \\
\hline 2009 & 830,943 & 83,113 & $-167,525$ & 1.11 & 0.83 & 0.11 & -0.17 & & \\
\hline 2010 & 814,973 & 67,143 & $-15,970$ & 1.09 & 0.98 & 0.09 & -0.02 & & \\
\hline 2011 & 962,415 & 214,585 & 147,442 & 1.29 & 1.18 & 0.29 & 0.18 & & \\
\hline 2012 & $1,121,238$ & 373,408 & 158,823 & 1.50 & 1.17 & 0.50 & 0.17 & & \\
\hline 2013 & $1,241,133$ & 493,303 & 119,895 & 1.66 & 1.11 & 0.66 & 0.11 & & \\
\hline
\end{tabular}

Source: Own calculations based on https://statistici.insse.ro/shop/index.jsp?page=tempo3\&lan $\mathrm{g}=$ ro\&ind $=$ TUR101B

Chart 10. The evolution of the number of tourists in mountain resorts, 2003-2013

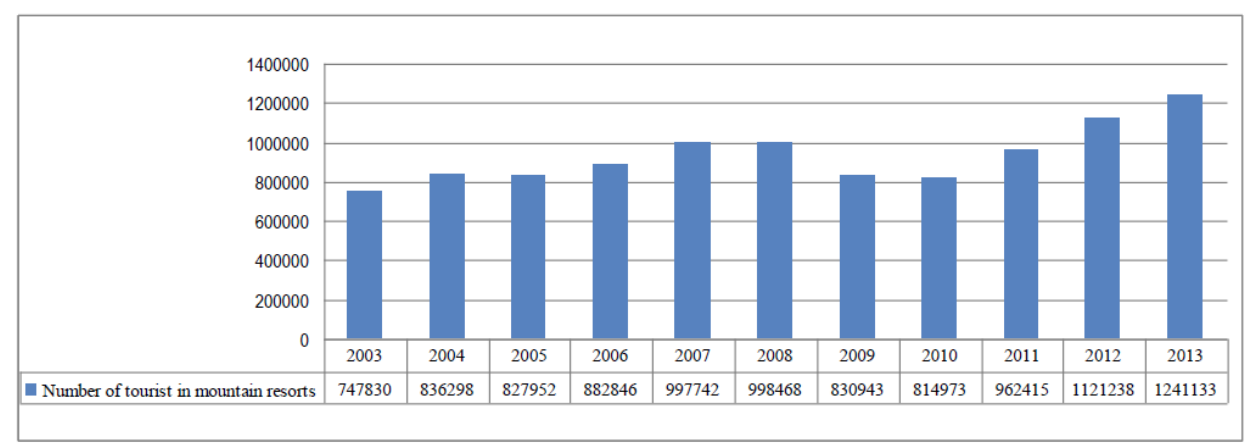

Source: Own calculations based on https://statistici.insse.ro/shop/index.jsp?page=tempo3\&lan $\mathrm{g}=$ ro\&ind $=$ TUR101B 
During the period between the years 2003-2013, the number of Romanian tourists who chose the Romanian mountain resorts represented an annual average of 49,330.3 persons per year. To assess the downward trend, for the following period (2015-2020), of the number of tourists' arrivals in the mountain resorts in our country, it was used the criterion based on average growth:

Table. 10. The calculation algorithm needed to adjust the evolution of tourist arrivals through the average growth $\left(\mathrm{y}_{\mathrm{t}}\right), 2003-2013$

\begin{tabular}{|c|c|c|c|c|c|}
\hline Year & $\mathbf{y}_{\mathbf{t}}$ & $\boldsymbol{\Delta}_{\mathbf{t} / \mathbf{t}-\mathbf{1}}$ & $\mathbf{t}-\mathbf{1}$ & $\mathbf{Y}_{\mathbf{t}}=\mathbf{y}_{\mathbf{1}}+\mathbf{( t - 1 ) \boldsymbol { \Delta }}$ & $\left(\mathbf{y}_{\mathbf{t}}-\mathbf{Y}_{\mathbf{t}}\right)^{\mathbf{2}}$ \\
\hline $\mathbf{2 0 0 3}$ & 747,830 & 0 & 0 & 0 & 0 \\
\hline $\mathbf{2 0 0 4}$ & 836,298 & 88,468 & 1 & $797,160.3$ & $1,531,759,561$ \\
\hline $\mathbf{2 0 0 5}$ & 827,952 & $-8,346$ & 2 & $846,490.6$ & $343,679,690$ \\
\hline $\mathbf{2 0 0 6}$ & 882,846 & 54,894 & 3 & $895,820.9$ & $168,348,030$ \\
\hline $\mathbf{2 0 0 7}$ & 997,742 & 114,896 & 4 & $945,151.2$ & $2,765,792,245$ \\
\hline $\mathbf{2 0 0 8}$ & 998,468 & 726 & 5 & $994,481.5$ & $15,892,182.25$ \\
\hline $\mathbf{2 0 0 9}$ & 830,943 & $-167,525$ & 6 & $1,043,811.8$ & $45,313,126,013$ \\
\hline $\mathbf{2 0 1 0}$ & 814,973 & $-15,970$ & 7 & $1,093,142.1$ & $77,378,048,195$ \\
\hline $\mathbf{2 0 1 1}$ & 962,415 & 147,442 & 8 & $1,142,472.4$ & $32,420,667,295$ \\
\hline $\mathbf{2 0 1 2}$ & $1,121,238$ & 158,823 & 9 & $1,191,802.7$ & $4,979,376,886$ \\
\hline $\mathbf{2 0 1 3}$ & $1,241,133$ & 119,895 & 10 & $1,241,133$ & 0 \\
\hline Total & $\mathbf{1 0 , 2 6 1 , 8 3 8}$ & \multicolumn{5}{|c|}{} & $\mathbf{1 6 4 , 9 1 6 , 6 9 0 , 0 9 7 , 2 5}$ \\
\hline
\end{tabular}

Source: Own calculations based on https://statistici.insse.ro/shop/index.jsp?page=tempo3\&lan $\mathrm{g}=$ ro\&ind $=$ TUR101B

\begin{tabular}{|c|c|}
\hline$\Delta$ & $49,330.3$ \\
\hline$\square$ & $932,894.3636$ \\
\hline Standard deviation $\sigma$ & $122,443.564$ \\
\hline Coefficient of variation $v$ & $13.13 \%$ \\
\hline
\end{tabular}

Source: Own calculations based on https://statistici.insse.ro/shop/index.jsp?page=tempo3\&lan $\mathrm{g}=$ ro\&ind $=\mathrm{TUR} 101 \mathrm{~B}$

Table. 10. Previsions of the number of tourist arrivals in mountain resorts, 2015-2020

\begin{tabular}{|c|c|c|}
\hline Anii & $\mathbf{t}-\mathbf{1}$ & $\mathbf{Y}_{\mathbf{t}}=\mathbf{y}_{\mathbf{1}}+\mathbf{( t - 1 )} \mathbf{\Delta}$ \\
\hline $\mathbf{2 0 1 4}$ & 11 & $1,290,463.30$ \\
\hline $\mathbf{2 0 1 5}$ & 12 & $1,339,793.60$ \\
\hline $\mathbf{2 0 1 6}$ & 13 & $1,389,123.90$ \\
\hline $\mathbf{2 0 1 7}$ & 14 & $1,438,454.20$ \\
\hline $\mathbf{2 0 1 8}$ & 15 & $1,487,784.50$ \\
\hline $\mathbf{2 0 1 9}$ & 16 & $1,537,114.80$ \\
\hline
\end{tabular}

Source: Own calculations based on https://statistici.insse.ro/shop/index.jsp?page=tempo3\&lan $\mathrm{g}=$ ro\&ind $=$ TUR101B 
In accordance to the preview from the table above, for the period 2014-2019, it turns out that there is an upward trend of the number of arrivals in the mountain resorts.

\section{Number of overnight stays}

In the evolution of the overnight stays number in the Romanian mountain resorts between 2003 and 2013, we can see a large variation. In the data provided by the National Institute of Statistics and processed in Table no. 12, we can see that the number of overnight stays reached a maximum value of 2,678,493 in 2013.

Table 12. The evolution of the number of tourists overnight stays in Romanian mountain resorts, 2003-2013

\begin{tabular}{|c|c|c|c|c|c|c|c|c|c|}
\hline \multirow[b]{3}{*}{ Year } & \multicolumn{3}{|c|}{ Absolute indicators } & \multicolumn{4}{|c|}{ Relative indicators } & \multicolumn{2}{|c|}{$\begin{array}{l}\text { Annual } \\
\text { average }\end{array}$} \\
\hline & \multirow{2}{*}{$\begin{array}{c}\text { Level } \\
\text { indicators } \\
\text { Number } \\
\text { of tourists } \\
\text { overnight } \\
\text { stays in } \\
\text { Romanian } \\
\text { mountain } \\
\text { resorts }\end{array}$} & \multicolumn{2}{|c|}{ Absolute changes } & \multicolumn{2}{|c|}{ Index dynamics } & \multicolumn{2}{|c|}{ Growth rate } & \multirow{13}{*}{ 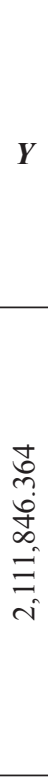 } & \multirow[b]{2}{*}{$\Delta$} \\
\hline & & $\Delta_{\mathrm{i} / 1}$ & $\Delta_{\mathrm{i} / \mathrm{i}-1}$ & $\mathbf{I}_{\mathrm{i} / \mathbf{1}}$ & $\mathbf{I}_{\mathrm{i} / \mathrm{i}-1}$ & $\mathbf{R}_{\mathrm{i} / 1}$ & $\mathbf{R}_{\mathrm{i} / \mathrm{i}-1}$ & & \\
\hline 2003 & $1,876,226$ & 0 & & & & 0 & & & \multirow{11}{*}{ 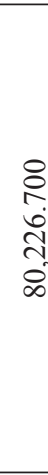 } \\
\hline 2004 & $2,060,351$ & 184,125 & 184,125 & 1.10 & 1.10 & 0.10 & 0.10 & & \\
\hline 2005 & $2,012,496$ & 136,270 & $-47,855$ & 1.07 & 0.98 & 0.07 & -0.02 & & \\
\hline 2006 & $2,062,047$ & 185,821 & 495,51 & 1.10 & 1.02 & 0.10 & 0.02 & & \\
\hline 2007 & $2,217,780$ & 341,554 & 155,733 & 1.18 & 1.08 & 0.18 & 0.08 & & \\
\hline 2008 & $2,245,756$ & 369,530 & 27,976 & 1.20 & 1.01 & 0.20 & 0.01 & & \\
\hline 2009 & $1,858,068$ & $-18,158$ & $-387,688$ & 0.99 & 0.83 & -0.01 & -0.17 & & \\
\hline 2010 & $1,772,859$ & $-103,367$ & $-85,209$ & 0.94 & 0.95 & -0.06 & -0.05 & & \\
\hline 2011 & $2,020,048$ & 143,822 & 247,189 & 1.08 & 1.14 & 0.08 & 0.14 & & \\
\hline 2012 & $2,426,186$ & 549,960 & 406,138 & 1.29 & 1.20 & 0.29 & 0.20 & & \\
\hline 2013 & $2,678,493$ & 802,267 & 252,307 & 1.43 & 1.10 & 0.43 & 0.10 & & \\
\hline
\end{tabular}

Source: Own calculations based on https://statistici.insse.ro/shop/index.jsp?page=tempo3\&lan $\mathrm{g}=$ ro\&ind $=$ TUR $103 \mathrm{C}$

As far as the number of tourists' overnight stays in the Romanian mountain resorts is concerned, the indicator is as well characterized by the same fluctuating evolution between 2003 and 2013. The minimum number of Romanian tourists' overnight stays was recorded in 2010 (1,772,859 overnight stays), specifically 905,634 less overnight stays than in 2013 (when there were recorded 2,678,493 overnight stays). 


\section{Conclusions}

The Romanian mountain area represents a domain of national interest, that has a significant economic, social, cultural and not lastly an environmental potential. The Romanian mountain area has a total of $71,341 \mathrm{~km}^{2}$, namely $30 \%$ of the national territory $\left(238,391 \mathrm{~km}^{2}\right)$. In the mountain area there are 3,270,793 inhabitants, representing approximately $20 \%$ of the population in the country (Erdeli, Gheorghilaş, 2006).

The Romanian mountain tourism has proved over time that it is a matter of competitive force on the domestic market, but too little present on the external market. From the multiple analyzes resulted that the opportunities of development are not far from being exhausted. To achieve this goal, the diversification and the increase of quality of supply must be taken as absolutely necessary. It must be noted the need for further transforming the Romanian mountain tourism, from a tourism concentrated in the coming months of the colder season, in a continue manifestation all year round, considering the fact that foreign tourists have made a tradition of coming in Romania, in particular during winter holidays. The mountain tourism in our country integrates all the elements necessary to develop, becoming an economic success by attracting foreign tourists (Neacsu et al., 2011). If the Romanian tourists prefer accommodation units of low comfort, it is not the way things are for foreign tourists, because they first choose to accommodate in units of 5 stars, followed by the 4 stars, the other categories of comfort being of no interest. Accommodation services providers will have to understand that attracting foreign tourists represents a desideratum, in this respect would have to be increased the degree of comfort of accommodation facilities.

One great advantage of the mountain tourism in our country consists of short distances from urban centres, which could reduce the time of travel. Unfortunately, small distances of travel are not supported by the general quality of infrastructure. A major problem of the Romanian tourism in general, as well as the mountain tourism in particular, consists of the lack of motorways or express roads and by default the low speed of travel. This inconvenience is doubled by the bad organization of the network of railroad, where, in addition to poor quality of services we also confront ourselves with very low travel speeds. According to the data supplied by CFR, the average driving speed of passengers' trains is of $45 \mathrm{~km} / \mathrm{h}$ ).

The Carpathians have allowed building a network of railways and road transport which connect localities situated outside the Carpathians' area with it. The mountain area is crossed by 38 primary and subsidiary railways, and some are related to the international routes. Road transport routes are much more and they get up into areas less accessible to the railway lines. The Carpathians are crossed by 4 European roads, the other being mostly updated, enabling access to the tourist resorts and objectives, but there is also a series of forest roads and marked paths to get to the areas where the update was not possible. The most spectacular roads in the Carpathians and a great deal of tourist interest are Transfăgără $\square$ anul in the Făgăra $\square$ Mountains and Transalpina in the Parâng Mountains. In a world where tourism is one of the most powerful sectors, Romania is still looking for another place.

Having a unique mountain tourism potential, both from the point of view of its natural attractions but also from a cultural - historical point of view, Romania is compelled to 
special attention to the policies and strategies of promotion. At one time, mountain tourism has entered in the shadow in the last period, being promoted in particular other forms of tourism, namely seaside tourism and bath tourism. Mountain tourism development should be dealt with in the light of the three directions, namely: financing, marketing, and education. In the first place, financing means providing a tax relief for tourism, allocating funds to promote treatments, at the same time, accessing the European funds and encouraging private investments in this sector. In respect of the marketing strategies is preferred the insurance of continuity both at macro-economic level as well as at the micro-destinations regardless of politics and changing governments.

Regarding education, the training programs are a requirement for the employment in this sector. A satisfied customer is a potential constant customer. There is no education for the "service" at present. In the approach of new marketing strategies should be taken into account the development of the educational system for tourism. Reviving the mountain tourism and acquiring new customers must be traced to a strategy of development by bringing together all those involved and interested in managing the valuable mountain potential of Romania.

\section{Literature}

1. Antonescu, D. (2014): The mountain regions in context of 2020 Strategy, MPRA Paper No. 56536, posted 11. June 2014 20:09 UTC, http://mpra.ub.uni-muenchen.de/ id/eprint/56536.

2. Arsene, O. (2009): Mountain tourism in Romania between theory and practice, Journal of Tourism Challenges and Trends, volume II, No. 1, pp. 145-151.

3. Cândea, M., Bran, F. (2001): Spațiul geographic românesc. Organizare. Amenajare. Dezvoltare, Economică, Bucureşti, România.

4. Dezsi, Ş. (2006): Patrimoniu şi Valorificarea Turismului, Presa Universitară Clujeană, Cluj, România.

5. Efros, V., Cheia, G. (2013): Mountain tourism interconnections. Variation of mountain tourist flow in Suceava county, Revista de turism, studii i cercetări în turism, No. 16 Suceava, pp. 67-71.

6. Erdeli, G., Gheorghilaş, A. (2006): Amenajări turistice, Universitară, Bucureşti, România.

7. Firoiu, D. (2002): Economia turismului şi amenajarea turistică a teritoriului, Sylvi, Bucureşti, România.

8. Lesenciuc, C., Boengiu, S., Hutupasu, M. (2013): The characteristics of the ski domains from the Romanian Carpathians, Forum geografic. Studii si cercetări de geografie si protectia mediului, volume XII, no. 1 pp. 93.

9. Marin-Pantelescu, A. (2009): Diversificarea si personalizarea serviciilor turistice in contextul globalizării, ASE, Bucureşti, România.

10. Neacsu, M., Neacsu N., Baron, P., Glăvan, V. (2011): Geografia si economia turismului, Pro-Universitaria, Bucuresti, România.

EP 2015 (62) 3 (849-868) 
11. Neacsu, M.C., Negu, S., Vlasceanu, G. (2014): The dynamic of foreign visitors in Romania since 1990. Current challenges of romanian tourism, The Amfiteatru Economic journal, vol. XVI, special issue 8, pp. 1340-1342.

12. Olaru, O. (2011): Turismul, fenomen economic-social specific epocii contemporane, Pro-Universitaria, Bucureşti, România.

13. Popescu, F. (2010): Spatial patterns of the ski areas from the Făgăra Massif and the Bucegi Mountains, Analele Universitătii din Oradea -seria Geografie, Tom XX, no. 2, pp. 284-285.

14. Slusariuc, G., Bîcă, M. (2015): Mountain tourism-pleasure and necessity, Ecoforum, vol. 4, pp. 119-122

15. Stănciulescu, G., Micu, C. (2009): Economie şi gestiune în turism. Probleme, proiecte şi studii de caz, C.H.Beck, Bucureşti, România.

16. Taylor, M., Yang, X., Strom, R. (2007): The Ski Resorts Industry in the TwentyFirst Century's First Decade a World-Wide Competition between Continents, Countries and Regions, in "Proceedings North American Case Research Association 2007 Annual Meeting”, Keystone, USA, pp. 1-17, .

17. Turnock, D. (1999): Sustainable Rural Tourism in the Romanian Carpathians, The Geographical Journal, The Changing Meaning of Place in Post-Socialist Eastern Europe: Commodification, Perception and Environment (Jul., 1999), Vol. 165, No. 2, pp. 192-199.

18. https://statistici.insse.ro/shop/index.jsp?page=tempo3\&lang=ro\&ind=TUR103C

19. https://statistici.insse.ro/shop/index.jsp?page=tempo3\&lang=ro\&ind=TUR101C

20. https://statistici.insse.ro/shop/index.jsp?page=tempo3\&lang=ro\&ind=TUR101B

21. https://statistici.insse.ro/shop/index.jsp?page=tempo3\&lang=ro\&ind=TUR101A 